IНТЕРМАРУМ: історія, політика, культура. - Вип. 7.

UDC 39(477) 94(73):654.191«Voice of America»

DOI $10.33287 / 112008$

Sukhobokova Olga, PhD., Associate Professor Associate Professor of the Department of Foreign Nations Modern and Contemporary History Taras Shevchenko

National University of Kyiv ol-ha@ukr.net ORCID: https://orcid.org/0000-0002-4140-3231

\title{
"WE SHALL TELL YOU THE TRUTH": "VOICE OF AMERICA" IN THE GLOBAL INFORMATION SPACE (1940-IES - BEGINNING OF THE XXI CENTURY)
}

\section{Abstract}

The aim of the article is to provide a complex survey of the American broadcasting station "Voice of America's" history since its establishment to the beginning of the XXI century. The methodology of the research is based on combination of the general and special historical methods and principles of historical cognition, namely scientificity, historicism, systematicity, objectivity. The principles of historicism, systematicity and scientificity provide for tracing the activity of "Voice of America" and its causal relationships with the historical and political background and, in particular, the foreign policy agenda of the US government. The objectivity principle is involved while highlighting the activity of the broadcasting station. Alongside with the critical analysis of the source base, it stands for defining the conceptual background of "Voice of America's" operation, its regularities and certain aspects. The principle of systematicity makes it possible to create a holistic image of a broadcaster's activity in 1940ies-at the beginning of the XXI century. Taking into account the specifics of the topic, the article employs an interdisciplinary approach actualized due to categorial and scientific-research instruments of other social and humanitarian sciences, particularly politology. 
INTERMARUM: history, policy, culture. - Issue 7.

The scientific novelty of the article is attained by a pioneer attempt in the Ukrainian historiography to conduct a complex analysis of "Voice of America's" activity throughout its history. The results obtained by the author prove that "Voice of America" has been an important constituent of the US policy in the global information space. Thereat, it is not a representative of a certain power or public group, the activity of journalists and editorial offices in forming the information content is independent and based on the principles of journalism ethics. Due to this factor, the broadcasting station has a reputation of an independent and reliable source of topical and balanced information. "Voice of America" has adapted to the qualitative transformations in the globalization epoch information space in the course of XX-XXI centuries and turned into a powerful multimedia system attracting the largest audience in the world.

Key words: "Voice of America", media, infowar, international broadcasting, propaganda, Western broadcasting stations, "enemy voices".

Introduction. The modern hybrid war initiated by the Russian Federation and the infowar as one of its major aspects, keep investigation of the XXI-century infowars, especially when it comes to the period of the Cold War when most of the instruments, now used by the Russian Federation, have been tested, and the most successful global expertise of the leading countries' international broadcasting, current. One of such broadcasters is the American radio broadcasting station "Voice of America" (VOA) established during World War II to provide information opposition to the US enemies. Eventually it has become an important means of information war with the USSR and transformed into the world most powerful broadcaster operating in the context of the USA foreign policy. It predetermines the importance of highlighting the "Voice of America's" activity together with the growing general interest to the history of broadcasting as a separate object of empirical research. The topicality of the issue in Ukraine is stressed by the fact that since 1949 the Voice of America Ukrainian Service operates in the country, and the Ukrainian audience is one out of ten most numerous ones in the world. Thus, the problem is of peculiar interest due to the history of Ukrainian broadcasting. 
IНТЕРМАРУМ: історія, політика, культура. - Вип. 7.

For now the historiography of the issue under analysis is not exhausted. There are few works by American researchers devoted to "Voice of America" with a particular focus on the Cold War period. Special mention should go to the monographs by D. Krugler and H. Shulman (Krugler, 1972, Shulman, 1990), articles focusing on separate aspects of VOA (Roberts, 2009, 2011; Piresein, 1967) and memoirs of the people engaged into its establishment (Houseman, 1979) or VOA operation throughout its history (Karmazyn, 2019). Notably in most of the works in the broadcasting and infowars history VOA stands as one of the Western "broadcasting voices" studied in their entirety (Graham, 2015). Post-Soviet and Ukrainian scholars also provide integral studies of the major Western broadcasting stations' activity ("Voice of America", "BBC", "Radio Liberty" etc). Among them of greatest value and interest for our research are works by Lithuanian scholar R. Pleikis devoted to the Soviet radio confrontation against the "Western voices" (Pleikis, 2002) and Ukrainian researcher Yu. Kahanov specializing in studying the influence of the Western broadcasting stations on the public opinion in the Ukrainian SSR (Kahanov, 2013, p. 191-203). The author of the given research devoted her numerous investigations to the history of VOA Ukrainian Service (Sukhobokova, 2009, p. 246-260; Sukhobokova, 2019, p. 663; Sukhobokova, 2020, p. 10-32), thus initiating studies of the general aspects of VOA activity in the national historical science.

The aim of the research is to conduct a complex survey of the history of "Voice of America".

The outline of the research. In the course of preparation of the USA for World War II at the order of President F.D. Roosevelt on July, 111941 the US Foreign Information Service (FIS) headed by the President's speechwriter Robert Sherwood and subjected to the US government was established. One of its primary tasks was to create a federal radio station to counteract the German propaganda in Europe. That same year a radio station "Voice of America" named by R. Sherwood was established in New York (Roberts, 2009). Its activity and finance were controlled by the Congress, and the station was subordinated to the FIS (VOA Through the Years; A Look Back). At that time there were two private operating companies established in 1931 and 1938 broadcasting in Europe, however they couldn't 
INTERMARUM: history, policy, culture. - Issue 7.

accomplish the large-scale tasks related to the US foreign policy intended for VOA (Roberts, 2009).

VOA beamed the first official broadcast on February, 24 1942, as mentioned in the vast majority of the studies. Although, one of the station's first directors Walter Roberts specified that the correct date of the first VOA broadcasting was February, 11942 (Roberts, 2011). The first radio program - a fifteen-minute address to the Europeans - was held in the German language. The announcer Willian Harlan Hale opened it with the words declaring the VOA fundamental official policy: "Today, and daily from now on, we shall speak to you about America and the war. The news may be good for us. The news may be bad. But we shall tell you the truth" (A Look Back).

The first VOA director, a famous American actor and producer John Houseman remembered the conditions in which the station was launched - nameless, without any studio facilities, using borrowed transmitters, without a single direction how to hold broadcasting except for telling the truth (VOA Through the Years). Definitely, the technical conditions the VOA staff had to work in were difficult - the first programs were held in a rented space in New York City, the material was broadcasted to Europe by the privately-owned American shortwave stations and over the facilities of the British Broadcasting Corporation (BBC). The core statement was about no instructions from above how to hold the program, just telling the truth. Since its establishment, the VOA leadership stressed that impartiality was the main principle of its activity. The first program declared the motto of the broadcasting station - "we shall tell you the truth". The truthful presentation of the events and "bad news" were considered to be the most efficient counter to the unforewarned Nazi propaganda. It was clear that under war conditions avoiding a certain tendency was impossible. Thus, there was good reason for VOA to broadcast from the Office of War Information (OWI) since June 1942.

Although the main goal of the station was to commit psychological pressure on Germany, soon afterwards the Voice could be heard in the English, French and Italian languages. In the second half of 1942 twenty-three short- and middlewave transmitters were constructed for VOA. In January 1943 twenty-seven VOA language services were on the air when the Allied summit took place in Casablanca (namely 
IНТЕРМАРУМ: історія, політика, культура. - Вип. 7.

Czecho-Slovak, Polish, Hungarian, Romanian, Yugoslavian and Finnish), and there were over forty in 1944 (A Look Back; VOA Through the Years).

In the course of a close victory over Germany and Japan, VOA was losing support from the state as far as its primary goal was finally achieved. In the late 1945 it was passed under the US State Department control, and in April 1946 the number of broadcasting languages was reduced to twenty-three, the working staff was downsized by two-thirds. The Congress reluctantly appropriated funds for the station's operation during 1946-1947 (VOA Through the Years).

However, the escalation of the Cold War initiated VOA activization: due to the decision of the Congress, it became one of the major instruments of ideological confrontation with the USSR, in particular, there was a direction to establish broadcasting in the USSR and the socialist countries. The VOA Russian Service was first to broadcast in the territory of the Soviet Union (February, 17 1947), followed by the VOA Ukrainian Service (December, 12 1949). It was the second Ukrainian radio broadcasting service operating in the West after "Vatican Radio".

The first national services headed for the USSR (Lithuanian, Latvian, Estonian and many others were created starting from 1951) played an extremely important ideological and political role in the infowar with the Soviet Union, as far as they encompassed the most numerous and potentially national liberation war-primed ethnic groups of the USSR. The importance of the VOA services for the ideological struggle between the USA and the USSR was confirmed by the appointed leaders in charge of these services. Thus, one of the first in charge of the Russian Service was Aleksander Barmine, a former intelligence officer who fled to the West and revealed the USSR, and the first director of the Ukrainian Service was an active participant of the Ukrainian National Liberation Movement, a leading official of the Ukrainian National Republic Nykyfor Hryhoriiv. Both were intransigent fighters with the Moscow communism (Sukhobokova, 2019, p. 578582).

Remarkably, during the Cold War period several Western stations called "enemy voices" were broadcasting in the territory of the USSR: "BBC" Russian Service - since 1946, "Radio Liberty" financed by the 
INTERMARUM: history, policy, culture. - Issue 7.

US Congress, "Deutsche Welle", "Vatican Radio", "Voice of Israel", "Radio France International" and others - since 1953. The broadcasting in the European countries of the socialist camp was represented by the station "Radio Free Europe" incorporated with "Radio Liberty" in 1975. The USSR security services blocked the broadcasting stations' programs by means of jamming the signal in its own territory and in the territories of the socialist countries and pursuing the listening audience. Nonetheless, jamming was of an irregular character and depended upon a situation in the American-Soviet relationship, when finally it was stopped in November 1988 according to the decision of the Political Bureau of the Central Committee of the Soviet Union Communist Party initiated by M. Horbachov (Pleikis, 2002).

At the beginning of the Cold War the officials in the American power circles debated the proper role of America's official international broadcasting service in the ideological confrontation with the socialist camp. The VOA tasks as seen by the Congress members varied from reporting the current news and acquainting with the USA to using it as a foreign policy instrument. Finally the latter position was approved by the Congress majority. The Korean War outbreak became a decisive argument to use VOA as "a weapon against the USSR" leading to increasing finance and expanding the staff of the broadcasting station. In the middle of 1951, VOA was broadcasting up to 400 hours per week in 45 languages (VOA Through the Years).

However, at the beginning of 1953 VOA, like most US state establishments, became a subject of inquiry by the US Senate Committee headed by Senator Joseph McCarthy. Although the charges levelled by McCarthy were never proven, VOA's budget and departments were significantly reduced and the program for constructing new powerful transmitters initiated in 1950 was halted. At the same time McCarthy's campaign provoked a review of US foreign information activities. A special commission appointed by President Dwight Eisenhower and chaired by former President Herbert Hoover to audit the US foreign information policy concluded that VOA was to be separated from the Department of State. Consequently, on August, 1 1953 the United States Information Agency (USIA) was established, and VOA became its major constituent with the headquarters on Independence Avenue in Washington not far from the US Capitol. A 
IНТЕРМАРУМ: історія, політика, культура. - Вип. 7.

special law on informational and cultural exchange programs, known as the Smith-Mundt Act, obliged USIA to "provide preparation and promotion of the information about the USA, its society and policy abroad through press, publishing, radio" (VOA Through the Years). That resulted in an essential extension of VOA broadcasting schedule, news blocks, educational and entertaining programs.

Despite the obvious relation of VOA to the political course of the US government, initially it was strictly regulated by the fundamentals of editorial and information policy of the broadcasting station. They were formulated in the VOA Charter developed by its founders headed by the director Henry Loomis (1958-1965) and approved by the USIA leader George Allen in 1960. It emphasized that the connection between peoples around the globe via radio served the American long-range interests and in order to be efficient VOA had to attract attention and adherence of the listening audience (Mission and Values). The final version of the Charter in the form of guidelines was signed by President Dwight Eisenhower. In July 1976 the VOA Charter was signed into law (Public Law 34-350) and sanctioned by President G. Ford. Its primary function was to "protect integrity and honesty of VOA programming". The Charted declared its independence from the state and government and outlined the major tasks and fundamentals of its operation - to serve as a consistently reliable and authoritative source of accurate, objective, and comprehensive news; to represent the USA, providing a balanced and comprehensive projection of all segments of American society, thought and institutions; to clearly and effectively present the US policy (The VOA Charter \& Journalistic Code).

The official documents highlighting the principles of the station's operation accentuated that it didn't represent the US government and any person or social group, and the journalists abided by the highest professional standards (Mission and Values). Adherence to the mentioned principles developed a reputation of VOA being a comprehensible and reliable source of information recognized even by the authorities of the USSR (Pleikis, 2002). At the same time, it is debatable why the VOA program broadcasting was forbidden in the territory of the USA until fairly recently.

The basis of the VOA information block in the Cold War period has been provided by political news, consideration and interpretation of 
INTERMARUM: history, policy, culture. - Issue 7.

the American and international events. For instance, in August 1963 VOA broadcasted an address "I have a dream" by Martin Luther King. The highest rate throughout its history VOA reached in 1969 when Neil Armstrong set foot on the moon - 450 million listeners around the globe. During the pro-democracy movement in Beijing's Tiananmen Square in 1989, a special "hot line" was started to receive calls from China, which blocked the VOA signal as the USSR did (VOA Through the Years). At the same time, being concerned about its reputation of a reliable information source, VOA was bound to shed light on controversial phenomena in the US social and political life that traumatized the nation, namely the war in Vietnam and the Watergate constitutional crises concerning R. Nixon's impeachment.

The VOA information policy during the Cold War period demonstrated a vivid correlation with the political situation in th world and the US reaction to it. Remarkably, such situation is actual in VOA activity nowadays. The VOA reacted immediately to the local conflicts between the USSR and the USA - VOA focused the listening audience's attention on the escalation of the conflict and initiated immediate broadcasting from the conflict zone. For example, during the Carribean crisis in 1962 VOA launched a Spanish-language broadcasting service and thus increased the amount of English-speaking information programs. During the war in Afghanistan in September 1980 VOA launched service broadcasting in the Dari language, and in 1982 - in the Pashtun language (VOA Through the Years).

The beginning of the 1980-ies was marked by technical and content modernization of VOA programming, connected with President R. Reagan's policy towards the USSR. In 1984 in his official claim he stated that VOA "had been a strict voice of truth", and "was capable of sending its messages of truth to the world" even despite the obstacles like out-of-date facilities and Soviet jamming. He also stressed that "the administration took measures for VOA modernization similar to those President Kennedy took for space programs" (VOA Through the Years). Putting VOA and space programs (well-funded by the USA) in one line proved the broadcasting station being one of the major instruments in the "psychological war" with the USSR.

Hence, to rebuild and modernize VOA programming and technical capabilities, a $\$ 1.3$ billion program was launched allowing to complete 
IНТЕРМАРУМ: історія, політика, культура. - Вип. 7.

new and upgraded radio transmission facilities, to construct nineteen upto-date studios, to install a new complex in Washington, to establish a net of controlling centres to coordinate VOA's domestic and overseas relay transmitter stations. During this period, some transformations in VOA editorial policy were held; consequently, alongside with providing analytic information, the programs were followed by editors' comments called "editorials", separated in an independent block of political news since 1982 (VOA Through the Years). The tradition is alive - editorials devoted to the US policy are broadcasted independently.

It was important that every national service except for promoting the VOA policy fundamentals had to be autonomous in creating its own program schedule and defining its content. For instance, the major operation content of the VOA Ukrainian Service was Ukrainian country-study cultural and educational activity initiated by its first director Nykyfor Hryhoriiv. Its broadcasting time was impressive enough - starting from a thirty-minute program in the end of 1949 up to five-hour broadcasting in every twenty-four hours for the Ukrainian population of the USSR and one hour for the Far East by the end of the Cold War. As of 1960 "Voice of America" broadcasted 16,5 hours daily for the USSR, eight hours in the Russian language, two - in the Ukrainian one. General duration of the "enemy voices" programs daily reached fifty hours in different stations and in different languages; forty hours daily were in Russian (Kahanov, 2013, p. 194).

The primary ideological task performed by all national services broadcasting in the USSR and its satellites, was contrasting the two contrary worlds and ways of life - the American and the Soviet ones. That was what the programs about public and cultural life of the Russian, Ukrainian and other emigrants in the USA and Canada, their self-determination, private business and political initiative, career and financial development etc. were aimed at. The broadcasted material of such character had a hidden political implication despite the absence of revealing announcements and hints. An essential fragment of broadcasting time was devoted to revelation of the totalitarian and occupational character of the Soviet Bolshevist authorities. Thus, the policy of the Central Committee of the Bolshevist Communist Party, directed against the Soviet peoples was in the focus of attention. As an example, the Ukrainian Service daily radio programs contained analytic 
INTERMARUM: history, policy, culture. - Issue 7.

shows discussing the character of the Soviet regime, national policy of the USSR, economy management methods, security services operation, repressions of the intellectuals, Ukrainian Famine Genocide of 19321933 etc. (Sukhobokova, 2020, p. 21-25)

The VOA's director D. Austin in charge of the station during 20062011, was close to the mark with his conclusion that the Cold War period was the most efficient and productive in VOA's activity taking into account the scale, content and results of its operation (Erlykh, 2011). The VOA's part in informing the citizens of the USSR was proved in a year before the USSR disintegration, when reliable information about the situation in the Soviet territory had an incredibly important meaning. For example, the Russian Service was one of the first to inform about an attempt to hold the national insurrection in August 1991, the USSR disintegration etc. In the same manner VOA was operationally observing collapses in the "national democracy" regimes in Central Eastern Europe (VOA Through the Years).

After the USSR and the socialist camp were disintegrated, a new geopolitical image of the world loomed on the horizon and marked a new period in VOA's history. There was a process initiated in the USA, restructuring the government authorities in charge of broadcasting overseas. The Bureau of Broadcasting established by USIA in 1990 consolidated the three foreign multimedia services - VOA, "Worldnet" Television and Film Service and Radio and TV "Marti". On April, 30 1994 President Bill Clinton signed the International Broadcasting Act (Public Law 103-236) establishing an International Broadcasting Bureau (IBB) and a Broadcasting Board of Governors (BBG) within the USIA to control the US civil foreign broadcasting. On October, 11999 the USIA was liquidated by the Congress (Public Law 105-277) and the BBG became an independent federal organization comprised by the IBB, "Radio Free Europe / Radio Liberty" (RFE / RL), "Radio Free Asia" (RFA) founded in 1994 and VOA (VOA Through the Years).

Global changes of the 1990-ies influenced the VOA's structure, initiated transformations in its policy and set new goals. The services broadcasting in Central Eastern Europe and the former Soviet republics continued their operation after the USSR's disintegration and played an important part in forming public societies in constitutional states and establishing democratic values like freedom of speech and independent 
IНТЕРМАРУМ: історія, політика, культура. - Вип. 7.

national mass media development in the CIS countries. In 1992 the VOA Ukrainian Service started the domestic broadcasting of its own programs and several FM stations and established VOA's correspondent offices in Kyiv and some other cities. Since January 1993, broadcasting of TV programs and TV channels streaming live was arranged (Karmazyn, 2019).

At the same time, there were new perspectives in VOA's operation according to the US foreign policy interests. The attention was largely focused on local conflicts threatening the regional and global stability. Since 1991 the station was making attempts to launch Tibetan broadcasting. In 1992 the Kurdish-language broadcasts to listeners in Iraq and Iran went into air. Of significant value was broadcasting in Yugoslavia: in 1993 VOA divided its Yugoslav Service into Croatian and Serbian Services. There was also Slovene Service operating independently. The Bosnian Service was established in 1996 and in 1999 the Macedonian Service was launched.

A new important trend was outlined in the middle of 1990-ies developing broadcasting in the Eastern part. The first program broadcasted on September 18, 1994 was "China Forum TV". In 1996 the Arabic Service together with Worldnet Television Service and the Middle East Broadcasting Centre (MBC) in London launched a program "Dialogue with the West." That same year a show "Round Table With You" aired in Iran by the newly-established VOA Persian Service acquired great popularity, covering over 25 per cent of the adult population (VOA Through the Years).

In 1994 VOA created its own Internet source, thus becoming the world first and largest Internet broadcaster (Kern, 2006). The official VOA's Internet site containing text, video and audio information available round the clock offered it in fifty-three languages by the end of 1999. But still, radio broadcasting was the most popular and available means of transmitting information in 1990-ies and the VOA's administration made overwhelming efforts to provide its proper development. In 1996 the station first aired from Central Africa. In 1998 the global VOA English Service started broadcasting twenty-four hours (VOA Through the Years).

A powerful technical base, highly skilled staff experienced in emergency conditions and broadcasting in the East provided VOA with 
INTERMARUM: history, policy, culture. - Issue 7.

the highest rates during the tragic events in New-York on September, 11 2001. VOA summoned its mediaresources to arrange the first-minutes presentation of attacking the New-York World Trade Centre and the Pentagon from every angle and in every available format. The VOA Arabic and Persian Services increased the broadcasting time immediately, "Worldnet" interrupted the regular streaming of five VOA's mediasatellites in order to ensure real-time information about the New-York tragedy. A real journalist success was instant interviewing one of the Taliban leaders Mullah Mohammed Omar, achieving greatest impact both in Western and Eastern parts of the world. Later VOA highlighted the American military campaign in Afghanistan. Traditionally, acting according to the US major foreign policy recommendations and targeting the local audience, broadcasting in the Dari and Pashtun languages was increased (VOA Through the Years).

In general the period of the 1990-ies - the beginning of the XXI century, like the post-war period, was transitive for VOA. After bipolar pattern of global arrangement and new image of international relationship had suffered a collapse, VOA reoriented its activity as far as the USA faced new threats and challenges. Radio and TV broadcasting in the countries of the Near East and Southeast Asia was significantly increased after the terrorist act of September, 11 2001. The priority task for VOA in the region was involving young Muslim audience. In order to reach the goal, in March 2002 VOA launched the weekly Arabiclanguage satellite "Sawa" (meaning "Together") broadcasting twentyfour hours; later, another VOA's satellite - Television "Alhurra" (meaning "Free") was established. In late 2002 VOA teamed up with "Radio Freedom" to create a station "Farda" (meaning "Tomorrow") broadcasting in the Persian language, and the Iran audience passed a million mark (VOA Through the Years).

One could observe a parallel broadcasting development in Afghanistan. In 2004 VOA organized a radio station called "Ashna" (meaning "Friend") broadcasting in the Dari and Pashtun languages; in 2006 the TV station "Ashna" was introduced. In the neighbouring Pakistan a youth-oriented radio station "Aap Ki Dunyaa" (meaning "Your World") was created streaming in the Urdu language. Since February 2007 a new VOA service was established to satisfy the 
IНТЕРМАРУМ: історія, політика, культура. - Вип. 7.

Muslim population in Somali, once again demonstrating VOA's operational reaction to new conflict points worldwide (VOA Through the Years).

Alongside with VOA's reorientation to the Muslim audience, since 2004 the station was suffering a consequential termination in radio broadcasting in Southern, Eastern and Central European countries acceding to NATO and European Union, and also in post-Soviet countries (Kiel, 2008). Ukraine was among these countries, as far as broadcasting was ceased in 2008 .

In consequence of the successful adaptation to the modern technologies advancement, VOA continued to develop and to use stateof-the-art technical facilities for broadcasting programs. Since 2005 VOA's radio and TV programs are streamed in a digital format. Its main website "VOANews.com" was rated the sixth among the best global broadcasters (Kiel, 2008). Nowadays VOA is the largest digital multimedia radioelectronic system (radio, TV, Internet, mobile applications, cable systems, satellite stations) streaming through satellites to the countries of Africa, Asia, Central and Southern America, Eastern Europe and the Near East. VOA broadcasts in forty-four languages 1500 hours a week, the global audience comprising 275 million people weekly (Mission and Values).

Conclusions. Consideration of the American radio broadcasting station "Voice of America" since its establishment in 1941 until the last decade proved it has always been an important constituent of the US information policy overseas. Created to counter the German propaganda during World War II, it became an instrument of the ideological struggle between the USA and the USSR during the Cold War period and served as an auxiliary means of reaching the US foreign policy goals. Finally, after the USA committed itself to combating the global terrorism and fundamentalism, VOA experienced reorientation to the East. For that matter, the history of VOA's activity encouraged us to treat establishing of VOA national services in certain regions in the context of resolution of the US foreign policy tasks.

Analysis of VOA's content denies it being a representative of the US government interests. The fundamentals of the station's operation since its establishment have been based upon the major principles of journalism ethics, legislatively recorded in the form of a special law, 
INTERMARUM: history, policy, culture. - Issue 7.

ensuring the reputation of an independent and reliable source of accurate, actual and balanced information. The main motto of the VOA's activity since 1941 until now has been "telling the truth", becoming the station's primary strategy line and thus constantly increasing its listening audience worldwide.

Despite considerable qualitative changes in the informational space in the globalization era and emergence of new challenges the media faces at the break of the XX-XXI centuries, VOA has successfully fit into the conditions. It has become the most powerful broadcasting multimedia system encompassing the largest world listening audience. It is next to impossible to immure the detailed VOA's 80 -year history in the format of a single article. The VOA's operation trends, comparative analysis of the content in national services and their blocks, correlation of VOA with the other world broadcasters, counteraction to its operation by certain countries, its influence on social and political atmosphere and promotion of particular ideas comprise interesting and independent perspectives of further research. An important perspective is to study the materials accumulated by VOA as sources of studying the historical, political, cultural and other issues. Doubtlessly, a sufficient potential of the topic deserves attention and being a subject of further studies.

\section{BIBLIOGRAPHY}

A Look Back.

https://www.insidevoa.com/a/history-voa-75thanniversary/3700428.html

Erlykh, E. (2011). «Enemy Voices» - «Voice of America». http://www.zman.com/news/2011/01/09/92425.html

Graham, S. (2015). Culture and Propaganda. The Progressive Origins of American Public Diplomacy, 1936-1953. London: Imprint Routledge, $284 \mathrm{p}$.

Houseman, J. (1979). Front \& Center. New York: Simon \& Schuster, $512 \mathrm{p}$.

Kahanov, Yu. (2013). «Enemy Voices»: ideological confrontation on radio waves in Soviet Ukraine (second half of the 20th century). Scholarly Works of the Faculty of History. Zaporizhzhya National University,( XXXV), 193-201. 
IНТЕРМАРУМ: історія, політика, культура. - Вип. 7.

Karmazyn, A.(2019). Some Recollections and Reflections Regarding My VOA Ukrainian Service Career (1987-2015). http://uaas.org.ua/karmazyn.html

Kern, K. (2006) The Voice of America: First on the Internet. http://www.chriskern.net/history/voaFirstOnTheInternet.html

Kiel, P. (2008). Voice of America to Cut Language Services. https://www.propublica.org/article/voice-of-america-to-cut-languageservices-709

Krugler, D. (1972). The Voice of America and the Domestic Propaganda Battles, 1945-1953. Columbia: University of Missouri Press, 246.

Mission and Values. https://www.insidevoa.com/p/5831.html

Piresein, R. (1967). An International Radio History... the VOA. Foreign Service Journal, (44) (February 1967), 23-25.

Pleikis, R. (2002). Censorship. https://profilib.website/kniga/126557/rimantas-pleykisradiotsenzura.php

Roberts, W. (2009) The Voice of America - Origins and Recollections. American Diplomacy, Oct. 26, 2009. http://americandiplomacy.web.unc.edu/2009/10/the-voice-of-america-2/

Roberts, W. (2011). The Voice of America - Origins and Recollections II. American Diplomacy, Jan.11, 2011. http://americandiplomacy.web.unc.edu/2011/01/the-voice-of-america/

Shulman, H.(1990). The Voice of America: Propaganda and Democracy 1941-1945. Madison. The University of Wisconsin Press, 1990, $282 \mathrm{p}$.

Sukhobokova, O. (2009). Ukrainian voice from overseas. Ukraine of the 20th century: culture, ideology, politics, (15/2), 246-260.

Sukhobokova, O. (2020). Ukrainian «Voice of America»: 70 Years on the Air. Sharing America's Story with Ukraine: The Voice of America's Ukrainian Service, 1949-2019. Cleveland: Ukrainian Museum-Archives in Cleveland, 10-32.

Sukhobokova, O. Ukrainian service of the «Voice of America». Encyclopedia of the history of Ukraine. «Ukraine - Ukrainian», (2), 663.

Sukhobokova, O. (2019). Way to the Will: Nykyfor Hryhoriyv (1883 - 1953). Kyiv-Vinnytsia: Tvory, 608 p. 
INTERMARUM: history, policy, culture. - Issue 7.

The VOA Charter \& Journalistic Code.

28.html

https://archive.is/20161120165209/http://www.insidevoa.com/p/57

VOA History. https://www.insidevoa.com/p/5829.html

\section{Сухобокова Ольга. «МИ РОЗПОВІМО ВАМ ПРАВДУ»: «ГОЛОС АМЕРИКИ॥ У СВІТОВОМУ ІНФОПРОСТОРІ (1940 РP. - ПОЧАТОК ХXI CT.)}

\section{Анотація}

Метою даної публікації $\epsilon$ комплексний огляд історії американської радіостаниії «Голос Америки» від ї̈ створення у 1941 . до початку XXI століття. Методологія наукового дослідження базується на поєднанні загальнонаукових $i$ спеціальних історичних методів та таких принципів історичного пізнання як науковість, історизм, системність, об'єктивність. Спираючись на принципи історизму, системності ци науковості вдалося простежити діяльність «Голосу Америки» та ї̈ причиннонаслідкові зв'язки з історичним і політичним контекстом, зокрема зовнішньополітичною лінією уряду США. При висвітленні діяльності радіостаниії було застосовано приниип об'єктивності. Поряд з критичним аналізом джерельної бази ие дозволило з'ясувати концептуальні засади роботи «Голосу Америки», ї закономірності та окремі аспекти. Приниип системності допоміг сформувати иілісну картину діяльності мовника у 1940-х рр. - на початку XXI cm. Також, зважаючи на специфіку теми, було застосовано міждисииплінарний підхід, реалізований через використання категоріального апарату та науково-дослідного інструментарію інших суспільно-гуманітарних наук, зокрема політології. Наукова новизна роботи полягає у тому, щзо в ній уперше в украӥнській історіографії здійснено спробу комплексного розгляду діяльності «Голосу Америки» впродовж його історії. $У$ результаті дослідження авторка приходить до висновку, щзо радіостаниія «Голос Америки» була $і$ залишається важливою складовою політики США в світовому інфопросторі. При иььому вона не є речником певної владної чи суспільної групи, робота ї̈ журналістів та редакцій у формуванні інформаційного контенту $\epsilon$ незалежною та трунтується на приниипах журналістської етики. 
IНТЕРМАРУМ: історія, політика, культура. - Вип. 7.

Це забезпечило мовнику репутацію незалежного $i$ достовірного джерела актуальної та збалансованої інформації. «Голос Америки» зумів не лише успішно адаптуватися до якісних змін в інформаційному просторі в епоху глобалізачї на зламі $X X-X X I$ століть, а й перетворився на найпотужнішу мультимедійну систему, що має одну з найбільших аудиторій в світі.

Ключові слова: «Голос Америки», медіа, інформаційна війна, іномовлення, пропаганда, західні радіостаниії, «ворожі голоси».

\section{Suchobokowa Olga. "POWIEDZIEMY PRAWDE”: “GLOS AMERYKI” W INFO PRZESTRZENI ŚWIATOWEJ (LATA 40. - POCZATEK XXI WIEKU)}

\section{Streszczenie}

Celem danej publikacji jest kompleksowy przeglad historii amerykańskiej radiostacji "Głos Ameryki” od jej powstania w 1941 r. do poczatku XXI wieku. Metodologia badań naukowych opiera się na połaczeniu ogólnonaukowych i specjalnych metod historycznych oraz zasad poznania historycznego, takich jak naukowość, historyzm, systematyczność, obiektywność. Opierając się o zasady historyzmu, systematyczności $i$ naukowości, udało się prześledzić działalność radiostacji "Głos Ameryki" oraz jej związki przyczynowo-skutkowe w kontekście historycznym $i$ politycznym, między innymi $w$ polityce zagranicznej rzadu USA. Zasada obiektywności została zastosowana $w$ zakresie działalności radiostacji. Wraz z krytyczna analiza bazy źródtowej pozwoliło nam to poznać koncepcyjne podstawy "Głos Ameryki”, jej prawidłowości i poszczególne aspekty. Zasada systematyczności pomogła stworzyć całościowy obraz działalności stacji w latach 40. XX wieku - na początku XXI wieku. Biorac również pod uwage specyfike tematu, zastosowano podejście interdyscyplinarne, realizowane za pomoca aparatu kategorialnego i narzędzi badawczych innych nauk spolecznych i humanistycznych, w szczególności politologii. Oryginalnościa naukowa pracy jest to, że po raz pierwszy w ukraińskiej historiografii podjęto próbę kompleksowego rozważenia działalności "Głos Ameryki" w catej jej historii. W wyniku przeprowadzonych badań autorka stwierdza, że stacja radiowa "Głos Ameryki” byta i pozostaje ważnym elementem polityki USA w światowej przestrzeni informacyjnej. Jednocześnie nie jest rzecznikiem określonej grupy rzadowej lub 
INTERMARUM: history, policy, culture. - Issue 7.

społecznej, a praca jej dziennikarzy i redaktorów $w$ zakresie tworzenia treści informacyjnych jest niezależna i oparta na zasadach etyki dziennikarskiej. Dzięki temu rozgłośnia zyskała reputację niezależnego $i$ wiarygodnego źródła aktualnych $i$ wyważonych informacji. "Głos Ameryki" nie tylko z powodzeniem dostosowata sie do zmian jakościowych $w$ przestrzeni informacyjnej $w$ erze globalizacji na przełomie XX $i$ XXI wieku, ale także stała się najpotężniejszym systemem multimedialnym z jedna z największych widowni na świecie.

Stowa kluczowe: "Głos Ameryki", media, wojna informacyjna, nadawanie $w$ języku obcym, propaganda, zachodnie radiostacje, "wrogie glosy".

The article was received 10.27.2019 Article recommended for publishing 12.04.2019 